ROCZNIKI PEDAGOGICZNE

Tom 11(47), numer specjalny - 2019

DOI: http://dx.doi.org/10.18290/rped.2019.11s-23

MAŁGORZATA PRZYBYSZ-ZAREMBA

\title{
UWARUNKOWANIA ZACHOWAŃ SUICYDALNYCH ADOLESCENTÓW - NA PODSTAWIE PRZEGLĄDU WYBRANYCH BADAŃ
}

\section{WPROWADZENIE}

Zjawisko zachowań suicydalnych adolescentów staje się coraz bardziej powszechne we współczesnym świecie. Jest to bardzo interesujący, a zarazem dość kontrowersyjny i skomplikowany problem, który pomimo wielu badań i analiz, nadal nie został do końca poznany, zbadany (Makara-Studzińska, 2001, s. 219-220). Z przeglądu literatury międzynarodowej wynika, że jest to problem, który rozwija się niebywale szybko i występuje niemal na całym świecie. Obecnie samobójstwo jest trzecią najczęściej występującą przyczyną śmierci, która stanowi 10\% wszystkich zgonów osób w wieku 15-19 lat (Wasserman, Cheng, Jiang, 2005, s. 114-120). Z Raportu Światowej Organizacji Zdrowia (WHO) wynika, że w czołówce krajów, w których zanotowano najwyższy wskaźnik samobójstw na 100 tys. osób, znajdują się: Litwa $(34,1 \%)$, Rosja $(30,1 \%)$, Białoruś $(28,4 \%)$, Węgry $(24,6 \%)$, Słowenia $(21,9 \%)$ oraz Ukraina (21,2\%). W Polsce wskaźnik samobójstw wynosi 16,9\% (WHO, 2014).

W niektórych krajach temat samobójstw jest jednym z ważnych zagadnień, nad którym prowadzone są dyskusje. Przykładem są tu m.in. Stany Zjednoczone, gdzie w roku 2014 samobójstwa były drugą najczęstszą przyczyną śmierci młodych ludzi w wieku 15-24 lat. W stosunku do roku 1999 odsetek samobójstw wzrósł o 50\% u kobiet w tej grupie wiekowej (z 3,0 do 4,6 na 100 tys.), natomiast w stosunku do mężczyzn wskaźnik wzrósł z 16,0 do 18,2 na 100 tys. Badania te wskazują, że grupą najbardziej narażoną na

Dr hab. Malgorzata Przybysz-Zaremba, prof. PWSZ - Państwowa Uczelnia im. Stefana Batorego w Skierniewicach, ul. Batorego 64c, 96-100 Skierniewice; e-mail: malgorzata.p_z@ interia.pl; ORCID: 0000-0003-2542-5104 
podejmowanie zachowań suicydalnych są nastolatkowie i młodzi mężczyźni (Yongwen, Pearlman, Deborah, Hill, Viner-Brown, 2016, s. 53-56). Wskaźnik samobójstw zwiększa się dziesięciokrotnie od preadolescencji do wczesnej dorosłości. Z japońskiego raportu statystyki „Vital” wynika, że największa liczba zgonów młodych ludzi związana jest z samobójstwami. Wskaźnik popełnianych przez japońskich nastolatków samobójstw odpowiada wskaźnikowi samobójstw nastolatków w świecie. W roku 1990 liczba ta wynosiła 4 na 100 tys. ludności i do roku 2010 podwoiła się (Kawabe, Horiuchi, Ochi, Oka, Ueno, 2016, s. 231).

Zasygnalizowane wybrane statystyki i badania wskazują, że zachowania suicydalne (samobójstwa) adolescentów stają się poważnym problemem większości krajów i często są zagadnieniem poruszanym w literaturze. Dyskusje nad uwarunkowaniami tego zjawiska są prowadzone przez specjalistów, badaczy, nauczycieli, psychologów, psychoterapeutów itp. Stąd też celem podjętych rozważań jest przegląd (wybranych) badań nad uwarunkowaniami zachowań suicydalnych podejmowanych przez adolescentów. Moim zamierzeniem jest poszukiwanie w badaniach tych czynników ryzyka, które mogą w największym stopniu przyczynić się do podejmowania prób samobójczych (samobójstw). Podkreślenia wymaga istotny fakt, iż nie zawsze w najważniejszym środowisku rodzinnym młodego człowieka zjawiska patologiczne przyczyniają się do powstawania zachowań suicydalnych, ale częstokroć są to czynniki niewidoczne gołym okiem (niemające charakteru patologii). Na ten aspekt również chciałabym zwrócić uwagę w tekście.

\section{UWARUNKOWANIA ZACHOWAŃ SUICYDALNYCH ADOLESCENTÓW - PRZEGLĄD WYBRANYCH BADAŃ}

Etiologia zachowań suicydalnych to bardzo złożony proces, który ma swoje podłoże w zróżnicowanych i wielorakich, często ze sobą zintegrowanych czynnikach oddziałujących na młodego człowieka, który - jak wskazuje Andrzej Bałandynowicz - nie chce umrzeć, ale ma wolę życia, tylko że w lepszych warunkach. Nie jest on w stanie sam sobie zapewnić takich warunków, a sygnały, które przesyła, nie są właściwie odczytywane przez najbliższe otoczenie (a nawet często niedostrzegane bądź ignorowane). Zdaniem Bałandynowicza około 50\% młodych ludzi wysyła takie sygnały, które mają na celu zwrócenie na nich uwagi, na problemy, których aktualnie doświadczają i uzyskanie pomocy (Bałandynowicz, 2002, s. 78). 
Pierwsze próby wyeksplikowania uwarunkowań zachowań samobójczych podejmowali psychoanalitycy, m.in. Z. Freud, który wskazywał, że przyczyn samobójstw należy doszukiwać się w utracie obiektu miłości, przeniesieniu z niego zaangażowania na siebie i w konsekwencji identyfikacji z nim. Poprzez samobójstwo człowiek podejmuje działania mające na celu zniszczenie siebie, zniszczenie ,ja idealnego” (za: Domańska, 2017, s. 187-201). Zdaniem Erwina Ringela w rozwoju człowieka najważniejsze są pierwsze sześć lat życia, które w znacznym stopniu „decydują o tym, czy w jednostce powstanie archetyp zaufania czy nieufności, czy radość życia obudzi się w nim, czy zgaśnie" (Domańska, 2017, s. 193). Odwołując się do słów Ringela należy stwierdzić, że pejoratywny wymiar oddziaływania środowiska rodzinnego jednostki może w przyszłości przyczynić się do przejawiania przez nią zachowań suicydalnych. Badania przeprowadzone na osobach po próbach samobójczych wskazują, że dysfunkcyjne i patologiczne środowisko rodzinne dziecka, w którym doznawało ono różnego rodzaju urazów psychicznych, w znacznym stopniu przyczyniło się do podejmowanych zachowań suicydalnych. Badania te jednocześnie potwierdzają, że czyny samobójcze nie rodzą się z dnia na dzień, ale stanowią o występowaniu syndromu presuicydalnego, który uzewnętrznia się m.in. poprzez zawężenie, agresję hamowaną i autoagresję oraz fantazje samobójcze (za: Domańska, 2017, s. 193). Syndrom presuicydalny jest pierwszym czynnikiem wskazującym na zagrożenie samobójstwem, natomiast drugim jest zapowiedź samobójstwa (Domańska, 2017, s. 194).

Dotychczasowy stan badań nad uwarunkowaniami zachowań samobójczych wskazuje na wiele różnych czynników, mających istotny wpływ na podejmowanie przez młodego człowieka zachowań suicydalnych. Poszukiwania owych czynników będę prowadziła wokół trzech głównych obszarów: rodziny i jej sytuacji/problemów, jednostki i jej problemów/zaburzeń oraz środowiska społecznego (lokalnego), w którym jednostka żyje/przebywa.

\subsection{CZYNNIKI RYZYKA ZACHOWAŃ SUICYDALNYCH MŁODYCH LUDZI ZWIĄZANE Z RODZINĄ I JEJ SYTUACJĄ (PROBLEMAMI)}

Jak wskazują różne publikacje naukowe, rodzina to kardynalne środowisko wychowawcze dziecka, w którym osadzonych jest wiele zróżnicowanych czynników (negatywnych/pozytywnych). Liczne badania prowadzone nad uwarunkowaniami zachowań samobójczych młodych ludzi wskazują, że największą rolę odgrywają czynniki bezpośrednio związane ze środowiskiem rodzinnym. Stanowi ono źródło zróżnicowanych determinantów niekorzystnie 
oddziałujących na adolescentów. Jednym z ważnych czynników jest brak poczucia bezpieczeństwa w rodzinie, będący niejednokrotnie skutkiem występowania $\mathrm{w}$ rodzinie problemu alkoholowego. Badania duńskie, przeprowadzone na próbie prawie 76 tys. uczniów szkół średnich oraz zawodowych, potwierdzają ten fakt. Celem tych badań było wskazanie zależności między problemem alkoholowym rodziców a samookaleczeniem, wyobrażeniami samobójczymi i próbami samobójczymi podejmowanymi przez młodzież. Z badań wynika, że w przypadku młodych ludzi, których rodzice nadużywali alkoholu, częściej dochodziło do samookaleczeń [chłopcy: OR = 1,59 (95\% CI 1,40-1,82); dziewczęta: OR = 1,84 (95\% CI 1,69-1,99)], myśli samobójczych [chłopcy: OR $=1,81(95 \%$ CI 1,59-2,06); dziewczęta: OR 1,74 (95\% CI 1,59-1,89)] i prób samobójczych [chłopcy: OR = 2,10 (95\% CI 1,63-2,71); dziewczęta: OR = 2,09 (95\% CI 1,80-2,42)] w porównaniu z młodzieżą wychowywaną w rodzinie niemającej problemu alkoholowego. Wyniki badań analizowano m.in. ze względu na płeć. I tak, dziewczęta wychowywane w rodzinie z problemami związanymi z nadużywaniem alkoholu przez rodziców częściej podejmowały próby samookaleczenia niż chłopcy z rodzin z problemami alkoholowymi rodziców. Natomiast nie stwierdzono różnic pod względem myśli samobójczych i prób samobójczych. Nie wystąpiły również różnice w zależności od płci rodzica z problemami alkoholowymi. Badanie to pokazuje, że młodzi ludzie pochodzący z rodziny z problemem alkoholowym rodziców częściej podejmują się samookaleczenia, mają myśli samobójcze i próby samobójcze (Veronica, Pisinger, Hawton, Tolstrup, 2018, s. 201-208).

Kolejne badania duńskie, przeprowadzone wśród młodych ludzi w wieku 14-27 lat, wskazują, że warunki rodzinne, w jakich wychowują się dzieci i młodzież, mają istotny wpływ na podejmowane zachowania samobójcze. Badania dowodzą, że pierwsze próby samobójcze młodych ludzi wiązały się z zaburzeniem psychiatrycznym u któregoś z rodziców, z zachowaniami samobójczymi rodziców, przemocą występującą w rodzinie oraz wykorzystywaniem dzieci i ich zaniedbaniem. Zaobserwowano zwiększone ryzyko tych zachowań wśród młodzieży i młodych dorosłych, którzy cierpieli na zaburzenia psychiczne lub upośledzenie fizyczne, byli legalnie więzieni, uzależnieni od narkotyków. Osoby te często nie miały ukończonej szkoły, nie przeszły szkolenia zawodowego oraz nie były zatrudnione. Stygmatyzacja, wykluczenie społeczne i zaburzenia psychiczne u młodzieży lub młodych dorosłych i ich rodziców zwiększają ryzyko prób samobójczych (Christoffersen, Poulsen, Nielsen, 2003, s. 350; por. Pierzchała, 2013; 2016; 2017).

Badania litewskie, przeprowadzone na próbie ponad 3,5 tys. młodzieży w wieku 13 i 15 lat, wskazują, że próby samobójcze podejmowane przez 
młodzież mają swoje podłoże również w innych czynnikach związanych ze środowiskiem rodzinnym. Badacze wymieniają m.in. strukturę rodziny, jakość komunikacji w rodzinie, monitorowanie rodzicielskie ${ }^{1}$ i przywiązanie, styl rodzicielski, czas rodzinny itd. $43 \%$ badanych nastolatków miało zaburzenia emocjonalne, prawie $24 \%$ poważnie rozważało próby samobójcze, prawie $14 \%$ popełniło samobójstwo, ponad 13\% próbowało popełnić samobójstwo, a ponad $4 \%$ potrzebowało leczenia $\mathrm{z}$ powodu próby samobójczej w poprzednim roku. $\mathrm{Z}$ badań wynika, że młodzież z rodzin pełnych miała częściej myśli samobójcze (LUB wahało się od 1,32 do 1,$35 ; p<0,05$ ) i podejmowała więcej prób samobójczych $(\mathrm{OR}=1,70,95 \%$ CI $1,38-2,09 ; p<0,001)$. U młodzieży z rodzin pełnych niektóre manifestowane zachowania samobójcze były w znacznym stopniu związane z niską satysfakcją w relacjach rodzinnych, niskim wsparciem ze strony ojca, niskim wsparciem emocjonalnym ze strony matki, niskim wsparciem rodzicielskim we współpracy ze szkołą, autorytarno-represyjnym stylem rodzicielskim ojca i zaniedbanym stylem rodzicielskim ze strony matki. Rzadszy był wpływ wspólnie spędzanego czasu w rodzinie. Zaburzona interpersonalna komunikacja w rodzinie przekładała się na komunikację młodzieży z rodzicami za pomocą mediów elektronicznych. U chłopców 15-letnich, którzy częściej komunikowali się ze swoimi rodzicami za pomocą mediów elektronicznych, stwierdzono częstsze przejawy podejmowania prób samobójczych, które niejednokrotnie wymagały interwencji lekarza bądź pielęgniarki. Nienaruszona struktura rodziny i słabe jej funkcjonowanie w badaniach tych było istotnym predyktorem myśli i prób samobójczych wśród młodzieży litewskiej (Zaborskis, Sirvyte, Zemaitiene, 2016, s. 1-15). Uważam, że jest to ważny czynnik, który należy wziąć pod uwagę w planowaniu programów interwencyjnych w zakresie zapobiegania zachowaniom suicydalnym adolescentów (por. Pierzchała, 2010, s. 72-79; 2015, s. 85-105; Przybysz-Zaremba, 2017, s. 55-71).

Przywołane badania wskazują na szereg różnorodnych czynników związanych z rodziną i jej sytuacją jako bardzo ważnych determinantów zachowań suicydalnych młodzieży. Czynniki te niejednokrotnie są ze sobą zintegrowane, a więc w działaniach pomocowo-wspierających wymagają zaangażowania wielu specjalistów. Warte uwagi jest m.in. podkreślenie, że w zapobieganiu zachowaniom samobójczym adolescentów istotna jest zmiana warunków ich wychowania, która ma wpływ na zmniejszenie ryzyka podejmowania zachowań suicydalnych.

\footnotetext{
${ }^{1}$ Badania przeprowadzone w Stanach Zjednoczonych (Meldrum, Connolly, Flexon, Guerette, 2015, s. 15-23) wskazują, że brak właściwej kontroli rodziców kształtuje niską samokontrolę nieletnich, co w konsekwencji prowadzi do podejmowania przez nich zachowań przestępczych, w tym także do zachowań suicydalnych.
} 


\subsection{CZYNNIKI RYZYKA ZACHOWAŃ SUICYDALNYCH ZWIĄZANE Z JEDNOSTKĄ I JEJ PROBLEMAMI}

Istotnym obszarem czynników ryzyka zachowań suicydalnych adolescentów jest sama jednostka i jej problemy, których bezpośrednio doświadcza. Badania przeprowadzone wśród młodzieży w Australii i Nowej Zelandii wskazują, że najsilniejszymi czynnikami ryzyka samobójstw młodzieży są przejawiane zaburzenia psychiczne (w szczególności zaburzenia afektywne, np. depresja, oraz zaburzenia związane z używaniem substancji psychoaktywnych i zachowania aspołeczne) (Beautrais, 2000, s. 420-436). Zaburzenia psychiczne, zwłaszcza ujawniające się w postaci zaburzeń depresyjnych, dotyczą nie tylko młodzieży czy osób dorosłych, ale coraz częściej również dzieci. W 90\% przypadków zachowań suicydalnych zaburzenia depresyjne są głównym ich źródłem (Szymańska, 2012, s. 12). Często powiązane są one również z używaniem różnych substancji, takich jak alkohol, narkotyki i inne substancje psychotropowe (Gromulska, 2010, s. 127-132). Badacze koreańscy (Kim, Ahn, Kim, 2016) wskazują, że obok wymienionych wyżej substancji istotnym czynnikiem zaburzeń depresyjnych prowadzących do zachowań suicydalnych jest płeć młodzieży. Młodzież doświadczająca stresu i depresji na tle odmiennej orientacji seksualnej (lesbijki, geje, biseksualiści) od dwóch do trzech razy częściej podejmuje próby samobójcze niż młodzież heteroseksualna (s. 1-11).

Brunon Hołyst (2004, s. 789-793) wskazuje, że źródłem zachowań suicydalnych są także zaburzenia psychiczne, do których - obok silnej depresji - zalicza: „inne zaburzenia nastroju, jak np. zaburzenia dwubiegunowe (stan charakteryzujący się okresami depresji, zmieniającymi się na okresy polepszonego nastroju, mogący trwać nawet przez wiele dni i miesięcy); impulsywność; uczucie beznadziejności”.

Często u młodych adolescentów z depresją związane są zaburzenia emocjonalne, które niejednokrotnie kształtują „rodzenie się” myśli samobójczych. Zdaniem Czesława Cekiery stan emocjonalny młodzieży sprzed i w czasie próby samobójczej ujawnia się m.in. silnym podnieceniem, zdenerwowaniem, stanem rozżalenia, poczuciem doznanej krzywdy, zniechęceniem, stanem depresji, poczuciem bezsensu życia, silnymi stanami agresji i autoagresji (Cekiera, 2003, s. 7-8). Są to czynniki ryzyka, które wpływają na narastanie skłonności samobójczych. W sytuacji braku możliwości rozwiązania problemu jednostka podejmuje próbę samobójczą jako ucieczkę przed problemem/ problemami. Badania meksykańskie ${ }^{2}$ prowadzone wśród młodzieży oraz ich

\footnotetext{
${ }^{2}$ Celem badań było określenie częstotliwości występowania depresji i myśli samobójczych wśród młodzieży w Meksyku, określanej jako SED, a także poznanie doświadczeń nauczycieli
} 
nauczycieli wskazują, że 10 z 31 uczniów miało uczucie beznadziejności lub pragnienia samobójstwa, a 16 było „umiarkowanie ciężko” przygnębionych. Wyniki kwestionariusza przesiewowego sugerowały, że 10 z 31 uczniów może mieć problemy z użyciem narkotyków lub alkoholu. Spośród ośmiu uczniów, z którymi przeprowadzono wywiady, czterech podejmowało próby samobójcze, a w przeszłości trzy kolejne osoby miały myśli samobójcze. Wskazywaną przyczyną rodzenia się myśli samobójczych i podejmowania samobójstw były konflikty społeczne i interpersonalne w domu i szkole. Wszystkie osoby, które podejmowały próby samobójcze, miały myśli samobójcze, które prawdopodobnie wiązały się z poważnymi problemami w rodzinie. Sześciu z badanych uczniów stwierdziło, że objęcie ich „specjalną edukacją” przyczyniło się do pozytywnego rozwoju emocjonalnego i psychicznego. Również nauczycielki, które uczestniczyły w badaniu (były to trzy kobiety, z którymi przeprowadzono wywiady), podejmowały w ciągu ostatnich trzech lat próby samobójcze. Głównymi przyczynami podejmowania prób samobójczych były wykorzystywanie seksualnie, a także poważne problemy rodzinne, które mogły być też podłożem do wykorzystywania seksualnego bądź na odwrót. Warte uwagi w niniejszych badaniach było to, że wszystkie osoby, z którymi przeprowadzono wywiady doświadczały agresji i przemocy. Prawie wszyscy nauczyciele zetknęli się z uczniami, którzy podejmowali próby samobójcze i czuli, że nie mają odpowiedniej wiedzy i kompetencji w zakresie pomocy, wsparcia i profilaktyki dotyczących tego problemu (Medina, 1997, s. 257-263). Badania te wskazują, że edukacja profilaktyczna w zakresie zachowań suicydalnych uczniów oraz ich nauczycieli powinna mieć charakter priorytetowy i być realizowana na wszystkich szczeblach edukacyjnych. Profilaktyka powinna prowadzić do tworzenia innowacyjnych programów profilaktycznych, w których wymiar edukacyjny byłby jednym z ważnych obszarów. W zależności od występujących czynników ryzyka, działania profilaktyczne powinny mieć wymiar holistyczny i obejmować, jak wskazuje Zbigniew B. Gaś (1993, s. 9), również przepisy i strategie zmierzające do eliminowania lub redukowania czynników predestynujących do rozwoju zachowań suicydalnych.

Zaburzenia depresyjne, jako główna determinanta zachowań suicydalnych adolescentów, stanowią zespół powiązanych ze sobą zróżnicowanych czynników warunkujących zaburzenia depresyjne. Mogą to być następujące czynniki:

i uczniów dotyczących myśli i zachowań samobójczych wśród nastolatków SED. W badaniu zastosowano Kwestionariusz Badań nad Depresją Becka (BDI) oraz Osobisty Kwestionariusz Badań Osobowych, które przeprowadzono w sześciu docelowych szkołach specjalnych w dwóch szkołach wiejskich w pobliżu granicy z Meksykiem. Przeprowadzono wywiady z ośmioma studentami i sześcioma nauczycielami. W badaniu uczestniczyło 31 osób. 
społeczna izolacja jednostki, choroby somatyczno-psychiczne, zaburzenia osobowości, różnego rodzaju sytuacje i wydarzenia, które niekorzystnie oddziałują na jednostkę, zaburzając jej dotychczasowe życie (Makara-Studzińska, 2013, s. 76). Annette L. Beautrais (2000, s. 420-436) wskazuje na różnorodne czynniki osadzone zarówno w osobie, jak i w środowiskach jej życia (w rodzinie, w środowisku społecznym). Autorka wymienia: upośledzenie społeczne i edukacyjne jednostki, okres dzieciństwa oraz niekorzystne sytuacje rodzinne, psychopatologię, indywidualne predyspozycje jednostki związane z odpornością na sytuacje stresogenne oraz czynniki społeczne, kulturowe i kontekstowe. Zachowania suicydalne młodych ludzi niejednokrotnie są następstwem niepożądanych sekwencji życia, w których wiele czynników ryzyka z tych dziedzin łączy się i to zwiększa ryzyko zachowań samobójczych.

Przedstawione czynniki ryzyka zachowań suicydalnych związane z jednostką i jej problemami to zaledwie niewielki „wycinek” problemów i sytuacji, które w kluczowy sposób oddziałują na jednostkę. Istotne są przede wszystkim cechy osobowości (zob. badania Preti, 2008, s. 519-533) jednostki, jej wiedza i umiejętności w zakresie rozwiązywania problemów i radzenia sobie z sytuacjami stresogennymi. Indywidualnymi cechami osobowości adolescentów, które zwiększają ryzyko popełnienia samobójstwa, są: poczucie beznadziejności, perfekcjonizm, impulsywność, wrogość, agresja oraz brak umiejętności radzenia sobie z problemami (Carr, 2004, s. 54-58). Szczególnie te aspekty należy wziąć pod uwagę $\mathrm{w}$ działaniach profilaktycznych.

\subsection{CZYNNIKI RYZYKA ZACHOWAŃ SUICYDALNYCH ZWIĄZANE ZE ŚRODOWISKIEM SPOŁECZNYM}

Ważnym obszarem oddziałującym na przejawy zachowań suicydalnych adolescentów jest najbliższe środowisko społeczne, w którym również tkwi wiele niekorzystnych czynników mających wpływ na młodego człowieka. Analizy w tym zakresie prowadzono m.in. w badaniach irlandzkich, których celem była identyfikacja cech społeczno-demograficznych i okoliczności śmierci związanych z wiekiem osób zmarłych na skutek samobójstwa. W badaniu przeanalizowano 121 kolejnych samobójstw, które miały miejsce w latach 2007-2012 w południowo-wschodniej części Irlandii (miasto i hrabstwo Cork). Dane pozyskano m.in. od koronerów ${ }^{3}$, informatorów rodzinnych i pracowników

\footnotetext{
${ }^{3}$ Koroner to urzędnik prowadzący śledztwo w sprawie nagłego zgonu jednostki. Próbuje dociec przyczyny zgonu.
} 
służby zdrowia. Dokonano porównania między osobami w wieku 15-24 i 2534 lata. Analizie poddano cechy społeczno-demograficzne zmarłego, metody samobójcze, historię nadużywania alkoholu i narkotyków oraz wyniki analizy toksykologicznej próbek krwi i moczu pobranych pośmiertnie. Przeprowadzono testy $\chi^{2}$ Pearsona i binarną analizę regresji logistycznej. $Z$ badań wynika, że alkohol i/lub narkotyki wykryto za pomocą analizy toksykologicznej dla większości próbki całkowitej $(79,5 \%)$, co nie różnicowało osób w wieku 15-24 i 25-34 lata (74,1\% i 86,2\%). W porównaniu z osobami w wieku 2534 lata, osoby w wieku 15-24 lata częściej popełniały samobójstwo przez powieszenie $(88,5 \%)$. Osoby młodsze były mniej podatne na śmierć przez celowe przedawkowanie narkotyków i zatrucie tlenkiem węgla w porównaniu ze starszymi osobami badanymi. Młodsze osoby, które zmarły między sobotą a poniedziałkiem, częściej przed śmiercią spożywały alkohol. Historie nadużywania substancji były podobne w obu grupach wiekowych. Badania te wskazują na konieczność stosowania w oddziaływaniach profilaktycznych strategii ograniczających nadużywanie substancji wśród osób w wieku 25-34 lata zagrożonych samobójstwem (Arensman, Bennardi, Larkin, Wall i in., 2016, s. 1-14).

Najbardziej rozpowszechnioną metodą samobójstwa w krajach europejskich jest powieszenie się. Osoby podejmujące tę próbę samobójczą najczęściej są pod wpływem alkoholu lub środków odurzających, które wcześniej zażywali w towarzystwie kolegów/koleżanek. Badania wskazują, że w krajach Europy Wschodniej prawie $90 \%$ mężczyzn i $80 \%$ kobiet popełnia samobójstwo pod wpływem alkoholu lub środków odurzających (Ajdacic-Gross, Weiss, Ring, Hepp, Bopp, Gutzwiller i in., 2008, s. 726-732). Ale na przykład w Stanach Zjednoczonych, Argentynie i Szwajcarii młodzi ludzie dopuszczają się samobójstw, wykorzystując broń palną, która w tych krajach jest łatwo dostępna. Z kolei w krajach Ameryki Łacińskiej i Azji samobójstw najczęściej dokonuje się poprzez zatrucia (tę metodę najczęściej wykorzystują kobiety) (Ajdacic-Gross, Weiss, Ring, Hepp, Bopp, Gutzwiller i in., 2008, s.726-732). W większości krajów europejskich oraz w Australii młodzi adolescenci podejmują próby samobójcze poprzez powieszenie (ta metoda najczęściej wybierana jest przez mężczyzn) (Pitman, Krysinska, Osborn, King, 2012, s. 2383-2392). Na wybór użytej metody wpływ ma kilka czynników, m.in. łatwość dostępu (Banda, Nijman, 2010, s. 315-328), popularność i kontekst społeczno-kulturowy (Kanchan, Menon, Menezes, 2009, s. 938-942). Analizując wybór metody samobójstwa, w kontekście uwarunkowań jego popełnienia, Biddle i współautorzy wskazują, że główną przyczyną wypływającą z decyzji o wyborze metody poprzez 
powieszenie się ${ }^{4}$ jest przekonanie, że właśnie ta metoda jest szybka, bezbolesna i „czysta”, nie uszkadzająca zbytnio ciała, ale pozostawiająca dręczący obraz dla innych (Biddle, Donovan, Owen-Smith, Potokar, Longson, Hawton i in., 2010, s. 320-325).

Analizując uwarunkowania zachowań suicydalnych adolescentów z perspektywy socjologicznej, należy powołać się m.in. na E. Durkheima, który wskazuje, że

[...] nasilenie samobójstw jest zależne od stopnia integracji grup społecznych. W grupach o wyższym stopniu integracji społecznej nasilenie samobójstw jest mniejsze niż w grupach o niskim stopniu integracji: a) częściej samobójstwa popełniają osoby bezdzietne niż mające dzieci; b) mniej podatne na samobójstwa są osoby żyjące w związkach małżeńskich niż osoby samotne; c) wśród katolików samobójstwa popełniane są rzadziej niż wśród protestantów, gdyż kościół protestancki jest słabiej zintegrowany w czasie wojen; d) kiedy dochodzi do wzmocnienia integracji społecznej i wzrostu poczucia wspólnoty narodowej i patriotyzmu; e) liczba samobójstw maleje (za: Domańska, 2017, s. 194-195).

Silna integracja jednostki z grupą może mieć dwa wymiary. Po pierwsze - pozwala korzystać ze wsparcia członków grupy, a ukierunkowanie na wspólny cel odwraca uwagę od własnych problemów jednostki, po drugie - może prowadzić do samobójstwa altruistycznego, które jest efektem zbyt nadmiernego (silnego) przywiązania jednostki do grupy, obowiązujących w niej zasad i norm. Jednostka dopuszcza się samobójstwa dla idei i zasad grupy (Sobkowiak, 2011, s. 49). Ten typ samobójstwa przybiera postać heroiczną. Badacze wskazują, że istotne znaczenie w podejmowaniu prób samobójczych ma więź społeczna (więź ze środowiskiem społecznym); gdy jest ona zakłócona, prowadzi do dezorganizacji społecznej. Wówczas jednostka nie jest w stanie realizować zadań na rzecz grupy. Pojawia się stan normatywnego chaosu w grupie, w którym jednostka nie wie, czym się kierować, a jej zachowania nie spotykają się ze społeczną aprobatą czy dezaprobatą, ponieważ „normy życia społecznego ulegają dewaluacji”, a „reguły gry” stają się niejasne (Sobkowiak, 2011, s. 50). We współczesnym społeczeństwie coraz częściej ujawnia się taki obraz, w którym w głównym miejscu ulokowane jest doświadczanie samotności i izolacja społeczna, która niejednokrotnie zastępowana jest nowymi technologiami (Internet, cyberprzestrzeń, telefon itp.). Ten mocno stechnologizowany świat

${ }^{4}$ L. Biddle i współautorzy (2010) swoje badania oparli na doniesieniach osób, które podejmowały próby samobójcze poprzez powieszenie, ale w konsekwencji udało im się przeżyć. 
prowadzi do osłabienia więzi społeczno-rodzinnych, których efektem może być kształtowanie się u młodego człowieka licznych zaburzeń psychicznych, a w konsekwencji podejmowanie prób samobójczych. Zdaniem M. Jarosz działania autodestrukcyjne podejmowane są często jako przejaw wyobcowania ze środowiska społecznego bądź rodzinnego w sytuacji blokady dążenia do pełnienia określonych ról społecznych (Jarosz, 2004, s. 104).

Środowisko społeczne to kolejny obszar, w którym tkwi wiele różnorodnych (pozytywnych/negatywnych) czynników ryzyka, często o charakterze zintegrowanym, które w sposób permanentny oddziałują na współczesnych adolescentów. Ich siła oddziaływania zależy przede wszystkim od cech osobowościowych jednostki, chociaż istotne znaczenie mają także czynniki związane ze środowiskiem rodzinnym. Im trudniejsze warunki życia, tym bardziej jednostka jest podatna na oddziaływania czynników społecznych, zwłaszcza gdy nie może liczyć na wsparcie ze strony najbliższej rodziny.

\section{PODSUMOWANIE I WNIOSKI DLA PRAKTYKI}

Uwarunkowania zachowań suicydalnych i próby samobójcze adolescentów są zróżnicowane. Dotychczasowy stan badań w tym zakresie nie wskazuje na jedną, konkretną przyczynę, ale na splot zintegrowanych czynników osadzonych w jednostce, jej środowisku rodzinnym oraz środowisku społecznym. Badacze analizują te uwarunkowania ze względu na różne czynniki (zmienne) oddziałujące na młodego człowieka. $Z$ przywołanych badań można wywnioskować, że jednym z ważnych determinantów warunkujących zachowania suicydalne są zaburzenia depresyjne, które również mają swoje podłoże w różnorodnych zintegrowanych czynnikach, a które często należy rozpatrywać wraz z uwarunkowaniami zaburzeń depresyjnych. Jak wynika z wielu badań, przyczyny zaburzeń depresyjnych i zachowań suicydalnych są ze sobą ściśle związane, a niekiedy takie same. Trudno jednak dokładnie wskazać, które z nich w większym, a które w mniejszym stopniu oddziałują na młodego człowieka, prowadząc go do samobójstwa.

Przedstawiony materiał, chociaż nie ma wymiaru pogłębionych analiz czynników ryzyka zachowań suicydalnych adolescentów, wskazuje na ich wielość i różnorodność, co tym samym daje podstawę do projektowania właściwych działań profilaktyczno-terapeutycznych w tym zakresie. W ramach postępowania profilaktycznego, działania należy rozpocząć od projektowania profilaktyki presuicydalnej, która obejmuje wiele zabiegów zapobiegawczych jeszcze przed pojawieniem się symptomów. W tym przypadku zaleca się, aby 
oddziaływaniem profilaktycznym objąć najbliższą rodzinę jednostki oraz środowisko społeczne (lokalne), w którym przebywa, wychowuje się. Przykładem działań profilaktyki presuicydalnej skierowanej do tych środowisk jest przede wszystkim edukacja, mająca na celu przygotowanie młodych ludzi do pełnienia ważnych ról społecznych, np. w małżeństwie czy rodzicielstwie. Istotne jest tu również kształtowanie pozytywnych postaw u wychowanków wobec samobójców, ich zrozumienia, akceptacji, życzliwości itp. Kolejnym działaniem zapobiegawczym jest podejmowanie profilaktyki tzw. objawowej, która obejmowałaby działania skierowane na konkretne symptomy, sygnały podejmowania przez jednostkę próby samobójczej. W tym przypadku zaleca się włączenie w działania profilaktyczne tych podmiotów (rodzina, szkoła, instytucje, z którymi młody człowiek współpracuje na co dzień), które w sposób bezpośredni są w stanie udzielić pomocy (Bałandynowicz, 2014, s. 31).

Andrzej Bałandynowicz (2014, s. 32), powołując się na B. Hołysta wskazuje, że profilaktyka suicydalna powinna obejmować pięć poziomów: „oddziaływania edukacyjne skierowane na całe społeczeństwo; oddziaływania na grupę potencjalnie zagrożoną wystąpieniem postaw presuicydalnych; oddziaływania instytucjonalne i pozainstytucjonalne skierowane na jednostki suicydalne; oddziaływania medyczne podejmowane w sytuacjach zamachu samobójczego; oddziaływania pomocowo-wspierające jednostki suicydalne, mające na celu kształtowanie właściwej postawy wobec życia, wobec samorealizacji, kształtowania umiejętności pokonywania trudności, a także powrotu do aktywnego życia społecznego".

Zachowania suicydalne adolescentów to bardzo zróżnicowany i złożony proces, wymagający podejmowania wielu zabiegów profilaktycznych we właściwym czasie, gdyż tylko to skutkuje ochroną jednostki przed popełnieniem samobójstwa.

\section{BIBLIOGRAFIA}

Ajdacic-Gross, V., Weiss, M.G., Ring, M., Hepp, U., Bopp, M., Gutzwiller, F. i in. (2008). Methods of Suicide: International Suicide Patterns Derived from the WHO Mortality Database. Bulletin of the World Health Organization, 86 (9), 726-732. doi: 10.2471/ BLT.07.043489 PMID: 18797649

Arensman, E., Bennardi, M., Larkin, C., Wall, A. i in. (2016). Suicide among Young People and Adults in Ireland: Method Characteristics, Toxicological Analysis and Substance Abuse Histories Compared. PLoS ONE, 11/29 (11), 1-14.

BaŁandynowicz, A. (2002). Reakcja społeczeństwa wobec problemu suicydalnego jednostki. W: B. Holyst, M. Staniaszak, M. Binczycka-Anholcer (red.), Samobójstwo (s. 78). Warszawa: Polskie Towarzystwo Higieny Psychicznej. 
Batandynowicz, A. (2014). Profilaktyka i prewencja zachowań suicydalnych w okresie adolescencji u dzieci i młodzieży. Resocjalizacja Polska, 6, 17-40.

Banda, B. L., NiJman, H. (2010). Suicide Inside: A Systematic Review of Inpatient Suicides. Journal of Nervous and Mental Disease, 198 (5), 315-328. doi: 10.1097/NMD.0b013e3181da47e2 PMID: 20458192

Beautrais, A.L. (2000). Risk Factors for Suicide and Attempted Suicide Among Young People. Australian \& New Zealand Journal of Psychiatry, 1 (34), 420-436.

Biddle, L., Donovan, J., Owen-Smith, A., Рotokar, J., Longson, D., Hawton, K. i in. (2010). Factors Influencing the Decision to Use Hanging as a Method of Suicide: Qualitative Study. British Journal of Psychiatry, 197 (4), 320-325. doi: 10.1192/bjp.bp.109.076349 PMID: 20884956

CARr, A. (2004). Depresja i próby samobójcze. Sposoby przeciwdziałania i reagowania. Gdańsk: Gdańskie Wydawnictwo Psychologiczne.

Cekiera, Cz. (2003). Wstęp do wydania polskiego. W: Zapobieganie samobójstwom. Poradnik dla nauczycieli i innych pracowników szkót (s. 7-8). Genewa-Warszawa: WHO, PTS.

Christoffersen, M.N., Poulsen, H.D., Nielsen, A. (2003). Attempted Suicide Among Young People: Risk Factors in a Prospective Register Based Study of Danish Children Born in 1966. Acta Psychiatrica Scandinavica, 11 (108), 350.

Domańska, J.M. (2017). Teoretyczne aspekty zjawiska samobójstw. Prace Naukowe Akademii im. Jana Długosza w Częstochowie, 26, (2), 187-201. doi: 10.16926/p.2017.26.36

GAś, Z. B. (1993). Profilaktyka uzależnień. Warszawa: Wydawnictwo Szkolne i Pedagogiczne.

Gromulska, L. (2010). Zdrowie psychiczne w świetle dokumentów światowej organizacji zdrowia. Przeglad Epidemiologiczny, 64, 127-132.

HoŁyst, B. (2004). Kryminologia. Warszawa: LexisNexis.

Jarosz, M. (2004). Samobójstwa: ucieczka przegranych. Warszawa: Wydawnictwo Naukowe PWN.

Kanchan, T., Menon, A., Menezes, R.G. (2009). Methods of Choice in Completed Suicides: Gender Differences and Review of Literaturę. Journal of Forensic Sciences, 54 (4), 938942. doi: 10.1111/j.1556-4029.2009.01054.x PMID: 19486437

Kawabe, K., Horiuchi, F., Ochi, M., Oka, Y., Ueno, S. (2016). Suicidal Ideation in Adolescents and Their Caregivers: A Cross Sectional Survey in Japan. BMC Psychiatry, 16, 231.

Kim, G.H., Aнn, H.S., Kiм, H. J. (2016). Type of Sexual Intercourse Experience and Suicidal Ideation, Plans, and Attempts Among Youths: A Cross-Sectional study in South Korea. BMC Public Health, 7 (16), 1-11.

Makara-Studzińska, M. (2001). Wybrane zagadnienia z problematyki suicydologii. Annales Universitatis Mariae Curie-Skłodowska, 26(17), 219-220.

Makara-Studzińska, M. (2013). Przyczyny prób samobójczych u młodzieży w wieku 14-18 lat. Psychiatria, 10 (2), 76-83.

Medina, C. (1997). Suicidal Behaviors and Factors Related to Suicide among Mexican American Youth Identified As Seriously Emotionally Disturbed in Rural Settings. W: D. Montgomery (red.), Promoting Progress in Times of Change: Rural Communities Leading the Way, March 26-29, San Antonio, Texas RC 020 986. Reports Research/Technical (143), Speeches /Conference Papers (150), 257-263. 
Meldrum, R.C., Connolly, G.M., Flexon, J., Guerette, R.T. (2015). Parental Low Self-Control, Family Environments, and Juvenile Delinquency. International Journal of Offender Therapy and Comparative Criminology, 5, 15-23.

PierzchaŁA, K. (2010). Zapobieganie samobójstwom w środowisku więziennym. Krakowskie Studia Małopolskie, 14, 72-79.

PierzchaŁa, K. (2013). Kapelan więzienny w procesie resocjalizacji penitencjarnej. Toruń: Wydawnictwo Adam Marszałek.

PierzchaŁa, K. (2015). Problem samobójstw w więzieniach na tle ogólnych trendów. Zarys statystyczno-socjologiczny problemu [The Problem of Suicide in Prisoners in the Background of General Trends. The Statistical and Sociological Problem's Outline]. Przeglad Więziennictwa Polskiego, 86, 85-105.

PierzchaŁa, K. (2016). Destygmatyzacja przestępców w świetle Magisterium Kościoła oraz poglądów na resocjalizację. Kraków: Oficyna Wydawnicza „Impuls”.

Pierzchala, K. (2017). Pedagogical and Theological Reflections on the De-Stigmatization Process [Refleksje pedagogiczno-teologiczne nad procesem destygmatyzacji]. Polish Journal of Social Rehabilitation (Resocjalizacja Polska), 13, 17-37.

Pitman, A., Krysinska, K., Osborn, D., King, M. (2012). Suicide in Young Men. The Lancet, 379 (9834), 2383-2392.

Przybysz-Zaremba, M. (2017). Zachowania suicydalne adolescentów - w kierunku „właściwej” profilaktyki (wybrane zagadnienia i działania). W: I. BieŃkowska, J. ModrzeJEWska (red.), Profilaktyczne aspekty zagrożeń bezpieczeństwa dzieci i młodzieży (s. 55-71). KrakówBielsko-Biała: Wydawnictwa Scriptum.

Preti, M.A. (2008). Suicide Ideation and Social Desirability Among School-Aged Young People. Journal of Adolescence, 31 (4), 519-533.

Sobkowiak, M. (2011). Przeciwdziałanie zachowaniom suicydalnym w pracy socjalnej. Gorzów Wielkopolski, file://C:/Users/user/Downloads/Mariusz\%20Sobkowiak\%20-\%20 Przeciwdzialanie\%20zachowaniom\%20suicydalnym $\% 20 \mathrm{w} \% 20$ pracy $\% 20$ socjalnej $\% 20(1)$. pdf [dostęp: 7.06.2018].

Szymańska, J. (2012). Zapobieganie samobójstwom dzieci i młodzieży. Warszawa: Ośrodek Rozwoju Edukacji.

Veronica, S.C., Pisinger, M., Hawton, K., Tolstrup, J.S. (2018). Self-Injury and Suicide Behavior Among Young People with Perceived Parental Alcohol Problems in Denmark: A School-Based Survey. European Child \& Adolescent Psychiatry, 2 (27), 201-208.

Wasserman, D., Cheng, Q.I., Jiang, G.X. (2005). Global Suicide Rates Among Young People Aged 15-19. World Psychiatry, 4, 114-120.

WHO. World Health Organization (2014). Preventing Suicide. A Global Imperative, http:// apps.who.int/iris/bitstream/10665/131056/1/9789241564779_eng.pdf?ua=1\&ua=1 [dostęp: 4.05.2017].

Yongwen, J., Pearlman, D., Deborah, H.N., Hill, J., Viner-Brown, S. (2016). Surveillance of Suicide and Suicide Attempts Among Rhode Island Youth Using Multiple Data Sources. Rhode Island Medical Journal, 99 (12), 53-56.

Zaborskis, A., Sirvyte, D., Zemaitiene, N. (2016). Prevalence and Familial Predictors of Suicidal Behaviour Among Adolescents in Lithuania: A Cross-Sectional Survey 2014. BMC Public Health, 16 (7/12), 554. 


\title{
UWARUNKOWANIA ZACHOWAŃ SUICYDALNYCH ADOLESCENTÓW - NA PODSTAWIE PRZEGLĄDU WYBRANYCH BADAŃ
}

\section{Streszczenie}

Tekst dotyczy uwarunkowań zachowań suicydalnych adolescentów. Na podstawie przeglądu (wybranych) badań dokonano weryfikacji czynników tzw. ryzyka, które w znacznym stopniu oddziałują na młodzież. Poszukiwania uwarunkowań zachowań suicydalnych prowadzone były wokół czynników ryzyka związanych z rodziną i jej sytuacją/problemami, tkwiących w jednostce oraz związanych ze środowiskiem społecznym. Całość opracowania kończy podsumowanie wraz z wnioskami dla praktyki.

Słowa kluczowe: zachowania suicydalne (samobójstwa); adolescenci (młodzież).

\section{CONDITIONING OF SUICIDAL BEHAVIOURS OF ADOLESCENTS - BASED ON SELECTED RESEARCH REVIEW}

\begin{abstract}
Summary
The text considers adolescents' suicidal behaviours conditioning. Basing on the (selected) research review, there was executed the verification of the factors of so-called risks which have a significant impact on the youth. Searching for the conditioning of the suicidal behaviours was conducted around the factors of risk related to the family and its situations/problems rooted in an individual as well as (factors) related to the social environment. The whole of this elaboration is completed with the summary along with some practical conclusions.
\end{abstract}

Key words: suicidal behaviours (suicides); adolescents (youth). 